\title{
The Librarian - A Redefined Profession for the 21st Century
}

\author{
Elena Tîrziman \\ Professor, PhD \\ University of Bucharest, Faculty of Letters \\ E-mail elena.tirziman@litere.unibuc.ro
}

The digital environment and related technologies transform the professions in the fields of Library and Information Sciences. The article tries to present the specificity of the librarianship professions in this new informational and communication context and to identify the skills and competences needed to effectively carry out specific activities in the digital age.The profession of librarian has undergone a spectacular transformation into one of the most complex professions. If for a long time it has been regarded as a humanist profession, it has been seen in the last few decades that we are finding it more and more as a socio-technical profession that necessarily requires library and information science, communication, ICT, foreign languages as well as solid general knowledge of various fields. The profession of librarian is a profession of socio-human and technical synthesis.

Keywords: librarianship; competencies; qualifications

\section{History}

Library has always been a social institution with different faces depending on the level of development of the society, on information circulation, and on the level of education of the information. The library of the Antiquity operated within temples and royal palaces and it was a symbol of social standing: a kingdom, a community were appreciated for their documentary collections and for the prestige of their scholars. Quite often, a written document had a sacred connotation and librarians were considered scholars.

During the middle Ages, they preserved and developed scholarly traditions and libraries function mainly within monasteries: their role was not only to keep documents, but also to copy manuscripts in the famous scriptoria, which saved part of the antique heritage. Librarians has the reputation of scientists or researchers.

During the Renaissance and the modern times, libraries as institutions reflected both society and community. The press had a decisive contribution to book availability, which resulted in a larger number of libraries with a wide variety of activities: national libraries, public libraries. Thus, access to culture and education is being democratised. Academic prestige is related to university libraries. Librarians become document specialists aiming at organising and managing documentary funds, and ensuring access to these funds.

\section{Current Context}

The $21^{\text {st }}$ century has brought about a revolution of traditional models of information and documenting: a wide range of changes within a short time, relatively difficult to understand by libraries, changes that force libraries to continuously adapt to the challenges of a changing society where information plays a determining role. Library as an institution has undergone an identity crisis: it is in a complementary or even competitive relationship with Internet.

Revista Română de Biblioteconomie şi Ştiința Informării = Romanian Journal of Library and Information Science ISSN 2559-5490, ISSN-L 1841-1940 • Volume 13 Issue 42017 pp. 101-108 https://doi.org/10.26660/rrbsi.2017.13.4.101

This work is licensed under a Creative Commons Attribution-NonCommercial-NoDerivatives 4.0 International License 
Libraries are not autonomous institutions: they are part of a social, educational, administrative, cultural subsystem that reflects all the changes in these fields (Rey, 2010). Therefore, an analysis or an evaluation of libraries can be done only if we take into account the context in which they operate. The context can be social, administrative, cultural, economic, or circumscribed to Information and Communication Technologies (ICTs). ICTs have brought unprecedented changes in libraries and their activities, thus changing librarianship and information professions.

Digital information and documentary resources purchased by libraries (most often as access licences) relieve institutions from specific activities such as traditional purchase, recording, cataloguing, indexing, etc., but they also bring about new activities and attributions. Libraries and librarians develop access and evaluation of information resources competencies, of user education to acquire information culture, of achieving information and knowledge management.

\section{National Referential Framework of Document and Information Professions}

In a context in which there is an ongoing debate on the status, place, and role of libraries in society, it is necessary to develop a national referential framework of the professions in Library and Information Science. The concern for this profession shows its social importance in a society determined and conditioned by information, where it should rank first.

A good example in this respect is France, where there are national referential frameworks for all professions. For library, information, and documenting professions, there are very developed and diversified referential frameworks per categories of institutions, per specialisations or simply theoretical ones developed by universities, professional associations aiming at consolidating professions and at ensuring proper professional training and integration in the professional and social environment of the professionals in the field (Marcerou-Ramel, 2017).

For Romania, a national referential framework of professions in Library and Information Science should also equally be:

- An inventory of professions in Library and Information Science correlated with the professions in the Classification of Trades in Romania (CTR) (updated with certain necessary corrections such as redefinitions of some professions, addition of new professions), a mission of professional associations and of academic specialisations;

- A descriptive referential framework for each profession necessary for the development of the specialisation sheet, the record of the profession, or of the job description;

- A referential framework of the ways and tools allowing professional licensing and evaluation (basic professional training ways, academic specialisations and continuous education, as well as an inventory of the tools allowing the acquisition of knowledge, abilities, professional practice, etc.).

Such a national referential framework should cover professions grouped per classes and categories and that represent the main activities and responsibilities of an information and documenting structure, and a concrete representation of this professional document would include:

- The occupational standard of the profession;

- A typology of the professions;

- The competencies necessary to each profession;

- The level of professional training for each profession;

- The record of the profession or the generic job description.

All these information could define a specific professional category at national level because it would reveal the types of Library and Information Science professions in our information and documenting structures (and in other institutions and organisations operating with information) in 
Romania; for each profession, we could define the necessary competencies, the forms of professional training and the required qualifications, the criteria and ways of professional evaluation; at national level, we could evaluate the evolution of the profession and corroborate the demands of the labour market and academic training both quantitatively and qualitatively.

The Occupational Standard for the trade of Librarian with higher education in Romania was developed because we needed to define the required competencies in basic and continuous professional training. The National Library of Romania sent to the Ministry of Labour, in 2012, the occupational standard for library professions. The standard was developed as a result of the development of occupational analysis for the trade Librarian (with higher education), basic group 2622 Librarians and specialists in other information services, code COR 262202 (Autoritatea Naţională pentru Calificări, 2012). This is the first version of the standard, with possible renewal of the contents every four years.

The occupational standard identifies the specific activities and competencies of library professions and somehow manages to define what a librarian is in Romania. Thus, according to the standard, a Librarian with higher education is a specialist in charge of organising an information and documenting structure and its information and documentary content, as well as of ensuring the access to information and documents for all types of beneficiaries. The trade is in continuous change and reconfiguration as a result of the evolution and spread of ICTs and of the evolution of human knowledge and of the diversification of the way the latter are represented. Librarians with higher education work within national, county, town, commune libraries, in specialised, academic, school, etc. libraries, in information and documenting centres, as well as librarian or specialist in information in different institutions.

To access the profession, one needs three categories of competencies named Titles and categories of competence units covering professional competencies and abilities, transversal competencies and general knowledge competencies - eight competence units (communication abilities, foreign language skills, basic competencies in mathematics, science and technology, information skills, ability to learn, social and civic competencies, entrepreneurial competencies, cultural competencies; general competencies - three competence units (organising one's own activity, observing legal stipulations regarding labour health and security and emergency situation security, observing environmental protection rules); specific professional competencies - eleven units of competence (information management of documents in libraries, management of documents specific to library activities, developing collections of documents, recording non-periodical documents, recording periodicals, processing document collections, preventive conservation of document collections, communicating document collections, recovering information, guiding staff from territorial structures, managing relations with beneficiaries). We need to say that the standard does not advance a unit of specific competencies for digital resources because they considered that ICTs are present in all library activities and, therefore, the competencies required by digital documents and their specific processes can be integrated in the other specific units.

For each unit of general or specific competencies, they establish the Level of responsibility and autonomy, Elements of competence, Criteria for the achievement associated with the result of the activity described by the competence element, Criteria of achievement associated with the implementing of the activity described by the competence element, and Context (Variable range, Knowledge).

The Typology of Professions in Library and Information Science is dynamic because they are increasingly diversified and complex, different in expression and content from the ones in the $20^{\text {th }}$ century and, in addition, new professions specific to the digital environment. The profession of librarian is a polyvalent profession including trades strictly related to the document and information such as cataloguer, indexer, bibliographer, editor, conserver, librarian with attributions strictly linked to library processes and also trades needing transversal competencies or competencies common to other professions such as researcher, manager with different 
responsibilities, engineer, computer specialist, mediator of information, etc. (Rey, 2010).

The National High School of Information Science and Libraries (Ecole Nationale Supérieure des Sciences de l'Information et des Bibliothèques), the most prestigious academic school in the field of Library and Information Science in France, developed a referential framework of the field including the new professions associated with information and document (ENSSIB, s.a.). Besides the fact that this referential framework could be a good model for the Romanian area, it is important to note that the new professions of information and document are not necessarily found in information and documenting structures: they can be found in absolutely any field of activity using information and needing activities and processes of organizing, identifying and using information. Such examples of new trades could be information broker, data and information architect, data analyst, site administrator, data and digital information manager, database administrator, knowledge manager, etc.

Specific competencies state the ability of a profession to understand and accomplish as well as possible the activities and processes involved. A competence is new in relation to the ensemble of competencies operating at some point in a profession if describing an attribution not exercised until then. When, in a profession, most competencies are new and operate in a professional context that is new or different from the common one, then we have a new profession.

The occupational standard Librarian with higher education degree describes quite in detail the competencies and qualifications needed for a person wishing to work in a Romanian information and documenting structure. It stipulates the competencies and aptitudes necessary for all library activities and processes and the general competencies related with different categories of people, effective oral and written communication, research, analysis and synthesis, assimilation of an important amount of information, management of diverse professional situations, flexibility, opening, and resistance to sustained intellectual effort. Access conditions are related to solid knowledge culture, foreign language skills, and computer skills (Autoritatea Naţională pentru Calificări, 2012).

The most demanding and frequent new competencies are determined by the digital environment and the use of ICTs. Thus, there are computer competencies (information systems, databases and different applications); competencies in organising and recovering digital information, competencies related to the understanding of the legal and economic contexts accompanying the information (intellectual property rights, access rights, etc.).

Digital products and services force librarians and specialists in information science to acquire specific competencies. At international level, to practice information trades, one needs such basic competencies as competencies in basic training, ICTs competencies, specific managerial competencies (document management, information management, and knowledge management), competencies in an expertise field (specialisation in the profession), and communication competencies (Nonthacumjane, 2011). These competence categories show the complexity of the profession under the influence of the digital environment and of increasingly demanding users. Equally important are complementary competencies such a linguistic competencies, public communication competencies, team work competencies, project management and coordination competencies, as well as leadership abilities, attachment for the profession, flexibility, etc. (Feret and Marcinek, 1999).

Professional training, training in a profession is closely related to the abilities and competencies of the profession. Professional training needs to keep up with the evolution of library and information science. First, the influence of ICTs changes and diversifies professional competencies resulting even in hyper-specialisations per activities or types of documents (e.g., in France, there are library professions of a certain level of specialization that can be practiced only by doctors in the field) (Jung, 2013). Second, the new trades of information and documenting are found not only in information and documenting structures but in absolutely any field of activity using information 


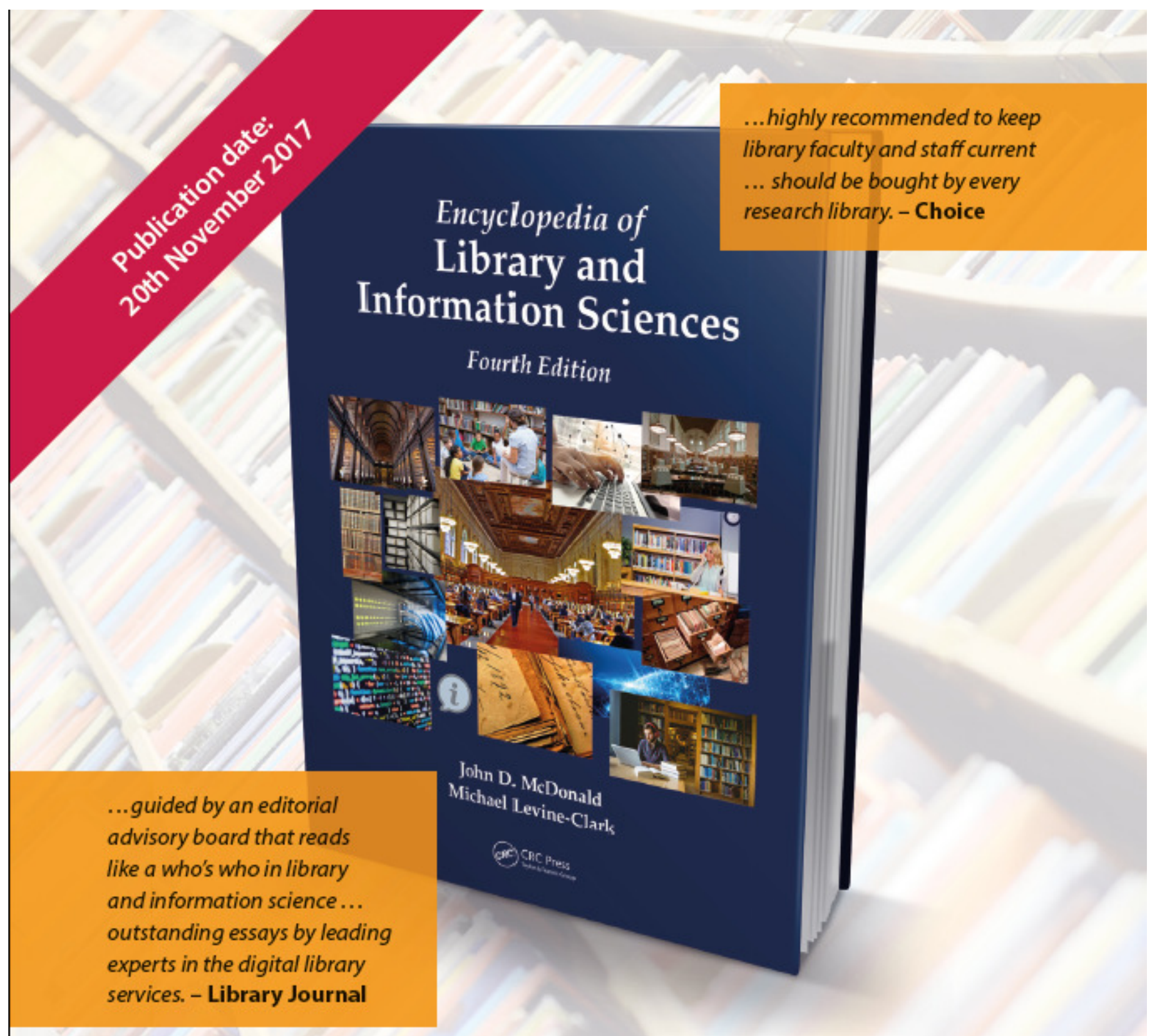

The Encyclopedia of Library and Information Sciences, now in its fourth edition, compiles the contributions of major researchers and practitioners and explores the cultural institutions of more than 30 countries. This major reference presents over 550 entries extensively reviewed for accuracy in seven print volumes or online.

The new fourth edition continues to reflect the growing convergence among the disciplines that influence information and the cultural record, with coverage of the latest topics as well as classic articles of historical and theoretical importance. 
and needing activities and processes of organization, recovery and use of information. We thus witness an extension of the labour market for the graduates from Library and Information Science.

Professional training can be achieved in two ways: academic and continuous education.

Academic training is achieved in Romania as in other European Union through three education cycles: $1^{\text {st }}$ - bachelor; $2^{\text {nd }}-$ Master; $3^{\text {rd }}$ - Doctorate. Bachelor is the basic academic training and Master and Doctorate are specialisations in the field.

Continuous training has become essential for library professions: they address people employed on the labour market and representing the way of facing the dynamics of information and the extraordinary evolution of associated trades.

To ensure the competencies needed by the professions on the labour market, we need a permanent link between professional associations and the institutions ensuring academic training or continuous education to define the proper curricula per categories and types of library professions.

The standard profession sheet or the generic job description should include (according to ADBS, 2007):

Name (it can be generic, e.g., Librarian, or assimilated names, e.g., Information and documenting system administrator, Database administrator, Digital content administrator, Specific application administrator, Information interface responsible, etc.). Such a name should be identifiable by its name precisely and without confusion;

Mission, basic responsibility (executive or leading positions, place in the organisational chart);

Professional evolution (professional steps and conditions for the promotion);

Necessary qualification level per professional level (medium or academic basic studies, specialisations such as Master or Doctorate, complementary qualifications);

Specific activities (detailed for each professional step);

Required competencies and aptitudes (basic competencies, complementary and transversal, personal);

Working context (relations within the organisational chart, interaction with other services or organizational structures);

Professional mobility (which professions could replace library and information science professions).

The standard professional sheet proves useful in the statement of the professional training requirements by licensed trainers in defining access requirements and in ensuring criteria and requirements of objective evaluation.

\section{Conclusions}

The trade of librarian has undergone spectacular changes becoming one of the most complex professions. If it has long been seen as a humane profession, the last decades have shown it is seen more and more as a socio-technical profession since it needs mandatory library and information science competencies, communication competencies, computer skills, language skills, as well as general knowledge from the most diverse fields. The trade of librarian is a socio-humane and technical synthesis trade.

We see, nowadays, an incontestable transformation of the professions related to document and information. Consecrated professions have undergone deep changes turning into extremely narrow specialisations for certain activities. Basic library activities need technological competencies and, in addition, new professions have emerged. 
Profession changes determine the need to train proper competencies, most of which are new competencies related to the digital environment. Transversal competencies are equally important in practicing a trade (such as basic competencies that are the core of professional activities).

Professional training needs to be a real symbiosis between theoretical development and real demands of the labour market; we also need cooperation between professional associations and trainers. Access to the profession is not possible without proper training. The human factor, professional competence play a determining role in the social success of information and documenting structures.

\section{References}

Accart, J.-P. and Réthy, M.-P. (2008) Le métier de documentaliste [The profession of documentalist], 3rd ed., Paris: Éditions du Cercle de la Librairie.

ADBS (2007) Référentiel des métiers et des fonctions de l'information-documentation [Referential framework of information-documentation professions and job positions], Paris: Association des professionnels de l'information et de la documentation (ADBS), available: https:// f.hypotheses.org/wp-content/blogs.dir/12/files/2009/04/referentiel-metier-rm.pdf [accessed 20.02.2018].

Association des Bibliothécaires de France (2007) Le métier de bibliothécaire [The librarianship profession], Paris: Éditions du Cercle de la Librairie.

Autoritatea Naţională pentru Calificări (2012) Standard ocupaţional bibliotecar (studii superioare) [Occupational standard for librarianship (higher education degree)], available: http:// www.anc.edu.ro/uploads/SO/Bibliot $\% 20$ st $\% 20$ sup final.pdf [accessed 20.02.2018].

Bibliothèque Nationale de France (2006) Référentiel des emplois et des compétences [Referential framework for job descriptions and library competencies]. Paris: Bibliothèque Nationale de France.

École Nationale Supérieure des Sciences de l'Information et des Bibliothèques (s.a.), available: www.enssib.fr [accessed: 20.02.2018].

École Nationale Supérieure des Sciences de l'Information et des Bibliothèques (s.a.) Les référentiels métiers [The referential frameworks of the professions], available: http:// www.enssib.fr/metiers-des-bibliotheques-et-de-la-documentation/travailler-en-bibliotheque/ referentiels-metiers [accessed 20.02.2018].

European Council of Information Associations (2004) Euroguide LIS, vol. 1, Competencies and aptitudes for European information professionals, Paris: ADBS Editions.

Feret, B. and Marcinek, M. (1999) The future of the academic library and the academic librarian: a Delphi study, Library Career Development, 7(10), pp. 91-107, available: https:// doi.org/10.1108/09680819910301898 [accessed 20.02.2018].

Gleyze, A. (2005) Quelles compétences pour les bibliothécaires? Diversité des fonctions et référentiels [What kind of competencies for librarians? Diversity of job positions and referential frameworks], Documentaliste-Sciences de l'Information, 42(1), pp. 22-25, available: https:// doi.org/10.3917/docsi.421.0022 [accessed 20.02.2018].

Jung, L. (2013) Former les bibliothécaires tout au long de la vie, pour quoi faire?: journée Médiadix, 30 septembre 2013 [Lifelong training of librarians, for doing what?: Mediadix day, September 30, 2013], Bulletin des Bibliothèques de France, 6, pp. 81-82, available: http:// bbf.enssib.fr/consulter/bbf-2013-06-0081-006 [accessed 20.02.2018]. 
Marcerou-Ramel, N. (2017) Référentiels métiers, référentiels de competences [Referential frameworks of professions, referential frameworks of competencies], Bulletin des Bibliothèques de France, 13, pp. 8-18, available: http://bbf.enssib.fr/consulter/bbf-2017-13-0008-001 [accessed 20.02.2018].

Micle, M. (2014) Stereotypes regarding libraries and librarians: an approach of Romanian school and academic libraries, Procedia - Social and Behavioral Sciences, vol. 163, Communication and Education in Knowledge Society, pp. 92-98, available https://doi.org/10.1016/j.sbspro.2014.12.291 [accessed 20.02.2018].

Moran, B.B. and Leonard, E. (2010) Academic librarianship, Encyclopedia of Library and Information Sciences, 3rd ed., Boca Raton, FL; London: CRC Press.

Nonthacumjane, P. (2011) Compétences et qualifications clés d'une nouvelle génération de professionnels des sciences de l'information et des bibliothèques [Key competencies and qualifications of a new generation of professionals in information science and libraries], available: https://www.ifla.org/past-wlic/2011/97-nonthacumjane-fr.pdf [accessed 20.02.2018].

Rey, L. (2010) Bibliothécaire: une profession en pleine évolution. De nouvelles compétences pour faire face à la transformation des technologies, des publics et des besoins [Librarianship: a profession in evolution. New competencies to deal with the transformation of technologies, users and needs], available: https://www.unige.ch/biblio/files/9214/1174/7148/Texte-conference.pdf [accessed 20.02.2018].

The American Library Association (s.a.), available: http://www.ala.org [accessed 20.02.2018].

The European Information Association (s.a.), available: http://www.eia.org.uk [accessed 20.02.2018].

Tîrziman, E. (2014) Biblioteca - spaţiu comunitar [The library - a space for community], Biblioteca, 25(4), pp. 99-100.

Tîrziman, E. (2017) Biblioteca digitală [The digital library], Tratat de Biblioteconomie, vol. III, București: Editura ABR, pp. 249-374.

Tîrziman, E. and Micle, M. (2016) Adapting Librarians' Professional Competences to Current Requirements through Initial Education and Lifelong Education, European Journal of Social Sciences Education and Research, 6(2), pp. 161-166, available: https://doi.org/10.26417/ ejser.v6i2.p161-166 [accesed 20.02.2018]. 